\title{
Measurement of Mechanical Properties of Carbon, New
}

\section{Devices}

\author{
Witold Biały \\ Institute of Production Engineering, Faculty of Management and Organization, Silesian University of Technology, Gliwice, Poland
}

\begin{abstract}
Proper selection of machines and equipment used in underground coal mining significantly influence the increase of their durability and reliability. The paper describes new, created in Poland devices to determine and evaluate the mechanical properties of the carbon (workability) whose co-founder is the author of this paper. These devices reflect the nature of the work of a plough and drum cutter-loader. It is presented their construction, operating principles as well as innovation and originality of used solutions. The devices are certified by enabling them to work in conditions of real mines, as a device intended for use in potentially explosive atmospheres. These devices have been awarded medals and diplomas at many International Fairs and Technological Innovation Exhibitions.
\end{abstract}

Key words: Workability, measurement, measurement methods, experimental research.

\section{Introduction}

Workability in the broad sense can be defined as interactions between the worked material and the working machine (tool). In its essence, it is resistance of the worked (fragmented) material against the working machine. For this reason, workability is included into mechanical properties of a mined useful mineral (hard coal, brown coal, rock).

It is practically impossible to define workability in a clear-cut way due to the fact that it is influenced by a very large number of factors - among others by the manner of mining.

In each of the above mentioned mining processes an important role is played by the applied technological process. Correlations between these processes are very loose, so the results obtained in one mining process cannot be approximated for another one.

In Polish hard coal mining the exploitation of coal beds takes places mainly in longwall systems, by means of mining machines the work of which is based on cutting. For this reason, one of important

Corresponding author: Witold Biały, Ph.D., Eng., prof., research fields: construction and operation of machinery and underground mining equipment, failure analysis, reliability, engineering of manufacturing processes. areas of a mining plant's activity is proper selection and use of equipment necessary to ensure the continuity of the mining process. Such activity should among others involve control over the rational and effective operation of equipment in the exploitation process.

Hence, a crucial element to be taken into consideration when designing and constructing the mining equipment is experimental research that reproduces the nature of a machine's work. The aim of such tests is to get to know the highest possible number of parameters and their influence on the work of a machine (its elements), which in turn affect the durability, reliability and effectiveness of mining in difficult, specific geological and mining conditions.

The further part of the article has been devoted to a description of two instruments constructed in Poland in the years 2011-2012. These instruments reproduce the character of work performed by a plow (GIG) and a cutter-loader ((POU-BW/01-WAP). The author of the article was a member of the team developing the concept, the principles of operation and the solutions applied in these devices. 


\section{Selected Methods of Coal and Rock Workability Measurement}

The importance of such issues as the measurement and evaluation of coal (rock) workability is confirmed by the number of methods and manners of measurement, which have been developed in various centres around the world.

Workability measurements were taken mainly for the needs of coal (underground) mining.

Among the methods of coal (rock) workability evaluation one can distinguish four basic groups, namely [1]:

I. laboratory methods,

II. recording of drilling resistance,

III. measurements of grindability,

IV. measurement of the forces of cutting with a single knife or a group of knives.

The first three methods are burdened with a considerable error, resulting mainly from the fact that the character of the mining machine has not been reproduced.

The fourth group includes methods in which instruments (devices) reproducing the real or similar character of a mining machine's work have been applied. Moreover, in this group of instruments we can distinguish the ones which reproduce the character of work performed by cutter-loaders or plows.

Devices whose work reproduces the character of plow's work include among others:

- ZP-1 (Czech Republic),

\section{- DMT (Germany).}

In Czech Republic the workability index B is defined as the ratio of average cutting force $\left(F_{s r}\right)$ on a measuring knife to the depth of the cut $(g)$.

$$
\mathrm{B}=\frac{F_{s r}}{g}\left[\frac{k N}{c m}\right]
$$

The DMT device is extensively applied for determining the conditions of a plow's work-proper location. Measurement consists in recording the cutting force when making a measurement cut having a depth of $2 \mathrm{~cm}$, by means of a standard knife placed on the measurement head. As opposed to research conducted in Poland, in coal beds classification only the averaged value of the force $\left(F_{S}\right)$ acting on the measurement knife is taken into consideration, as the depth of the cut is assumed to be a constant value [7]. On the basis of the adopted methodology and conducted investigations, a classification which divides coal beds into four groups has been developed (Table 1).

On the other hand, devices whose character of work reflects the character of work performed by a cutter-loader include such instruments as:

- DKS, SDM (Russia),

- POS-1 (Poland).

In these devices the workability index $\mathrm{A}$ is defined as a ratio of average cutting force $\left(F_{\dot{s}}\right)$ on the measuring knife to the depth of the cut $(g)$.

$$
\mathrm{A}=\frac{F_{s r}}{g}\left[\frac{k N}{c m}\right]
$$

Moreover, in Poland another workability index $-\mathrm{A}_{\psi}$ has been introduced; it takes into consideration the side-crumble angle $\psi$ and is equal to the equation as follow $[1,2]$ :

$$
\mathrm{A}_{\psi}=\frac{F_{s r}}{g\left(1+\frac{g}{b} \operatorname{tg} \psi\right)}\left[\frac{k N}{c m}\right]
$$

where:

$\mathrm{b}$ is the width of the cutting tool edge.

Table 1 Classification which divides coal by DMT.

\begin{tabular}{lll}
\hline Coal class & The average value of force & Level of difficulty \\
1 & $\mathrm{kN}$ & cutting \\
2 & $\mathrm{~F}_{\mathrm{s}}<1.5$ & well machinable \\
3 & $1.5<\mathrm{F}_{\mathrm{s}}<2.0$ & normally machinable \\
4 & $2.0<\mathrm{F}_{\mathrm{s}}<2.5$ & difficult machinable \\
\hline
\end{tabular}

Source: based on Ref. [12]. 
Table 2 The of new classification of Polish coals with regard to the mineability.

\begin{tabular}{lllll}
\hline Coal workability index & \multicolumn{3}{c}{ The side-crumble angle $\psi\left[^{\circ}\right]$} & Level of difficulty cutting \\
\cline { 2 - 4 } $\mathrm{A}\left[\frac{\mathrm{kN}}{\mathrm{cm}}\right]$ & $\psi>70^{\circ}$ & $40^{\circ}<\psi \leq 70^{\circ}$ & $\psi \leq 40^{\circ}$ & \\
\hline $\mathrm{A} \leq 1.80$ & $\mathrm{I}$ & - & - & Easy mineable \\
$1.81<\mathrm{A} \leq 3.00$ & - & II & - & Mean mineable \\
$\mathrm{A}>3.01$ & - & - & III & Hard mineable \\
& ${\text { Soft } \mathrm{W}_{\mathrm{k}}}$ & Hard $\mathrm{W}_{\mathrm{t}}$ & Very hard $\mathrm{W}_{\mathrm{bt}}$ & \\
\hline
\end{tabular}

The conducted research and the obtained results allowed modifying the classification of Polish coals into three categories, depending on the side-crumble angle $\psi$ and the value of workability index A (Table 2); these values are closely correlated with each other $[2$, 3].

Moreover, the above mentioned instruments enable taking measurements not only in laboratory conditions, but also under "in situ" conditions. Investigations carried out in underground conditions reflect the state of stress and deformation which occurs in real geological and mining conditions.

Another noteworthy research was conducted at the Technical University in Istanbul, which has a positive recommendation of the International Rock Mechanics Association as a standard for laboratory measurement of workability. Workability in this research is described by means of SE index, which is calculated as a ratio of the force acting on the cutting knife over the length of the cut $(F N)$ to the volume of broken rock $(Q)$ [4].

$$
\mathrm{SE}=\frac{F N}{Q}\left[\frac{M J}{m^{3}}\right]
$$

The index value exerts a considerable influence on the power, efficiency as well as durability of mining machines. It can be then concluded that this parameter has a decisive impact on the durability, installed power and dimensions of a mining machine and, in consequence, influences the costs of purchase and exploitation.

For this reason, coal workability measurement enables an optimal selection of mining machines' parameters and can be one of decisive factors making it possible to evaluate the effective exploitation of a particular plot or coal bed. This problem concerns coal mining by means of both a cutter-loader and a plow.

\section{New Tools for Determining the Workability Index}

\subsection{Instrument Reproducing the Work of a Plow}

The device for measuring the cutting forces, which reproduces the character of a plow's work, was constructed in GIG (Central Mining Institute) in Katowice [5, 6]. It allows a uniform and stable feed-in of the measuring knife to the coal solid, ensures high accuracy of coal solid preparation over a maximum length of $1 \mathrm{~m}$, guarantees high precision of performing the measurement cuts in it and enables accurate measurements of parameters necessary to determine the rock cutting index. The device allows cuts to be made with two turns - a measurement of coal resistance to cutting in coal beds having the thickness of 0.6-2.0 m, making a minimum of 10 measuring cuts with one mounting of the device at one height, without a necessity to move it, which conditions the precision of measurements. The device is easy to install and operate, which translates into low maintenance costs.

The device for determining the coal cutting index consists of four elements (Fig. 1):

(1) guide 1 fixed to hydraulic props 2 ,

(2) carriage 3 driven by hydraulic motor 4 ,

(3) chain wheel 5 and chain 9,

(4) feed-in assembly 6 .

Guide 1 with carriage 3 equipped with a holder for mounting a levelling knife (head) 7 or a cutting-measuring knife 8 , driven by hydraulic motor 4 , is fixed to hydraulic props 2 (Fig. 1). The drive is transmitted by means of chain 9 , fastened on chain 


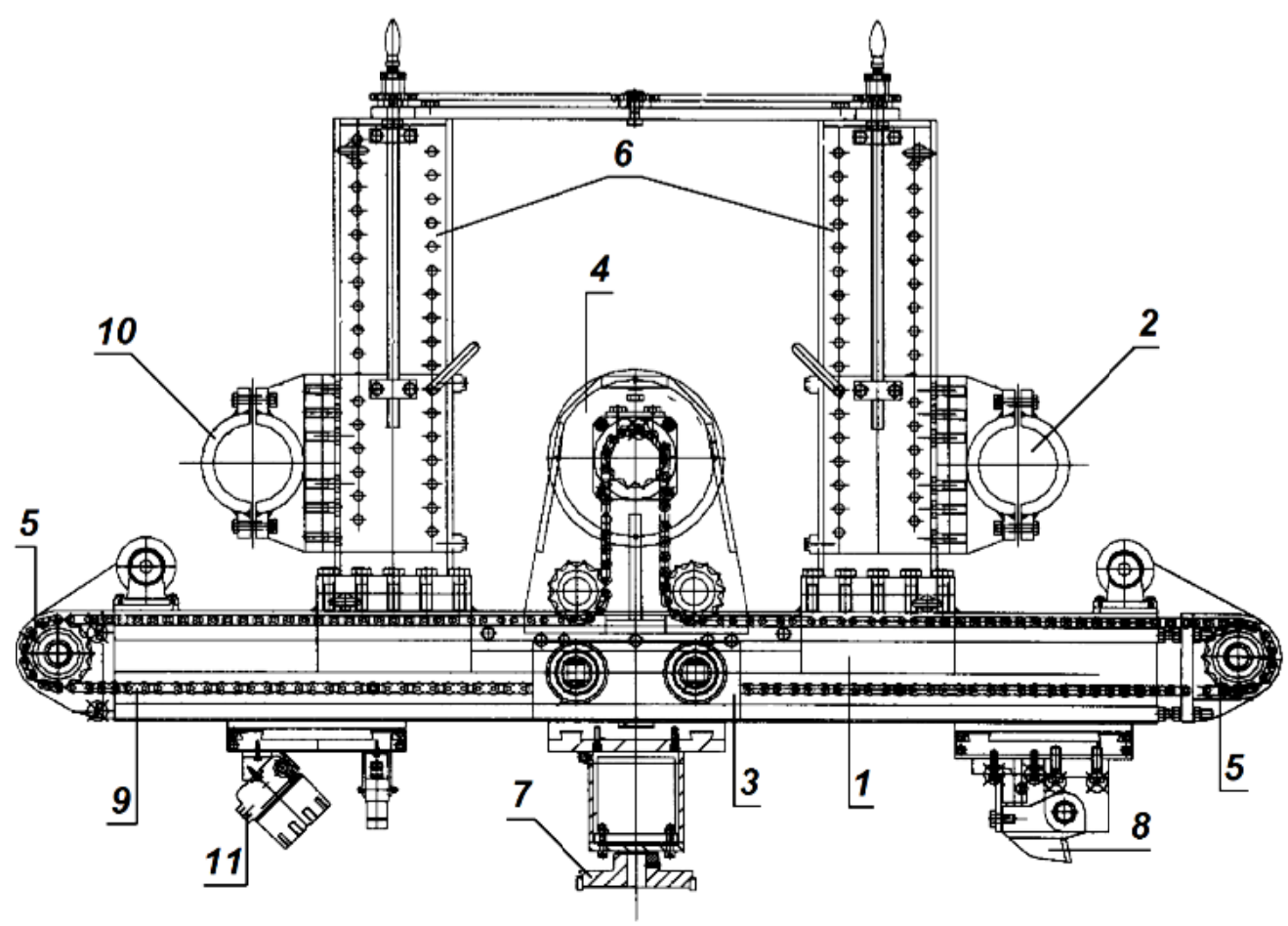

Fig. 1 The GIG device for measuring the cutting forces.

wheels 5. The device is equipped with a feed-in assembly 6 , which consists of two consoles connected with the hydraulic props by means of clamping rings 10.

The cutting forces are measured in four stages. Before proceeding to measure the cutting forces, it is necessary to level the coal solid surface-stage 1 . It is done by means of a levelling head equipped with a furnished hydraulic motor 7. The next step (stage II) is to install a levelling head and equip it with a scanner 11 in order to scan the levelled surface. The next stage (III) involves furnishing a head with a cutting-measuring knife 8 in order to take a measurement by recording the resistance to cutting. After the measurements have been taken, the cutting-measuring head is dismantled and the scanning head is installed again in order to scan the obtained groove (stage IV). On the basis of the recorded values of resistance to cutting (forces) and the computed volume of mined rock, its workability index is calculated. In order to make subsequent measuring grooves at the same height, the presented procedure should be repeated. The adopted methodology of measurements assumes that minimum three measuring grooves on one level in a coal bed are made.

\subsection{A Device Reproducing the Work of a Cutter-Loader}

POU-BW/01-WAP (POU- $\mathrm{a}$ device for determining workability, BW-Bialy Witold, WAP — Welding Alloys Poland-producer), installed and ready to work, has been presented in Fig. 2 [7-10].

It consists of three main elements (Fig. 2):

- carrying beam to be installed on props $\mathrm{SHC} / \mathrm{SHI} 1$,

- support with actuator's carriage 2,

- arm with a measuring knife 3.

The POU-BW/01-WAP device for determining the workability of coal enables making the cuts in a vertical plane (perpendicular to the roof and floor) with two turns. This instrument reproduces the real character of a drum cutter-loader's work, as the measurement cut has a changeable direction of cutting, starting approximately with a horizontal direction, through a vertical one, and finishing with a horizontal direction, which however has an opposite turn at the end. 


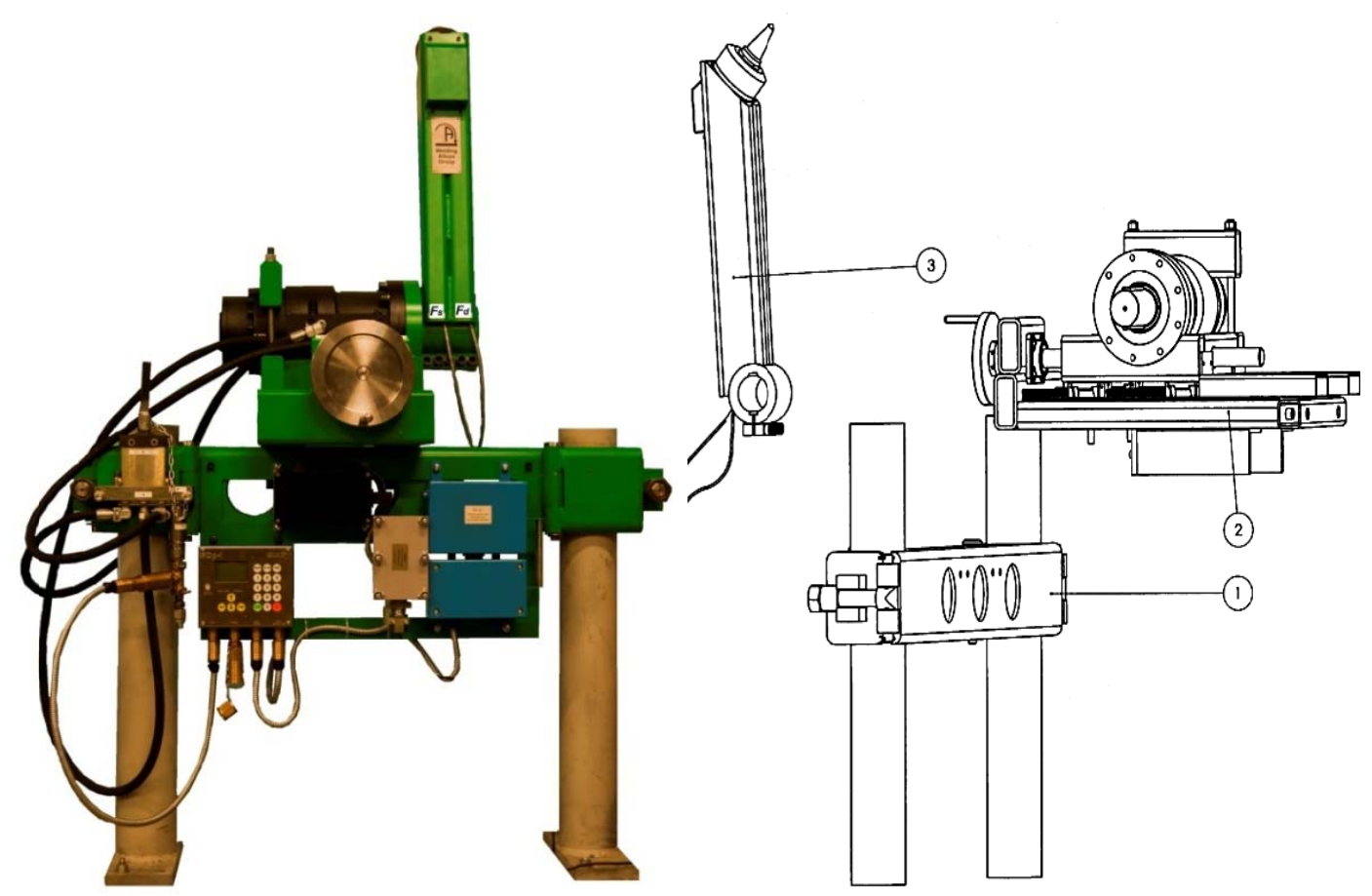

Fig. 2 The device and a device elements POU-BW/01-WAP.

Moreover, the POU-BW/01-WAP instrument (Fig. 2) enables the measurement knife to be moved closer to the coal solid by means of support 2 , which is fixed on frame 1 . The construction of the support ensures high accuracy of coal solid preparation and a similarly high precision of the performed cuts and measurements of parameters necessary to determine the coal workability index. A real knife that is installed in drum cutter-loaders (tangential-rotary) has been applied in the device as a measuring knife, thanks to which it is not necessary to take into consideration the influence of the knife's geometry on measurement results. In the previously applied devices the measurement's knife geometry was similar to that of real knives, which entailed the necessity to take into account the influence of the knife's geometry on the cutting force value in measurement results.

The device is adapted to be mounted on two SHI/SHC props. After the props have been initially aligned, the carrying beam must be fixed at a height of minimum $720 \mathrm{~mm}$ away from the base to its upper surface (Fig. 2), with the frontal area directed towards the coal bed (side wall) and mounting openings - to the top. After initial aligning and levelling, the beam should be screwed with two bolts.

The support with an actuator's carriage is fixed to the upper part of the beam (Fig. 3), in one of possible positions - the actuator's shaft should be located on the right side. The choice of the support's position is optional and depends on the conditions at the place where measurements are taken. It is possible to mount the support in one of two positions left/right and front/back by using appropriate holes in the beam and the support (Fig. 3).

After the support has been initially positioned, it is necessary to accurately adjust the distances by means of a knob equipped with a scale (Fig. 3). The knob enables forward movement of the carriage as well as its withdrawal. One full turn of the knob shifts the support by $7 \mathrm{~mm}$ - one division on the scale means a shift by 1 $\mathrm{mm}$.

The last element of the device is the arm, the end of which is equipped with a measurement knife (Fig. 4). The arm's knife should be directed towards the mined bed (side wall).

When the mechanical elements have been assembled, 

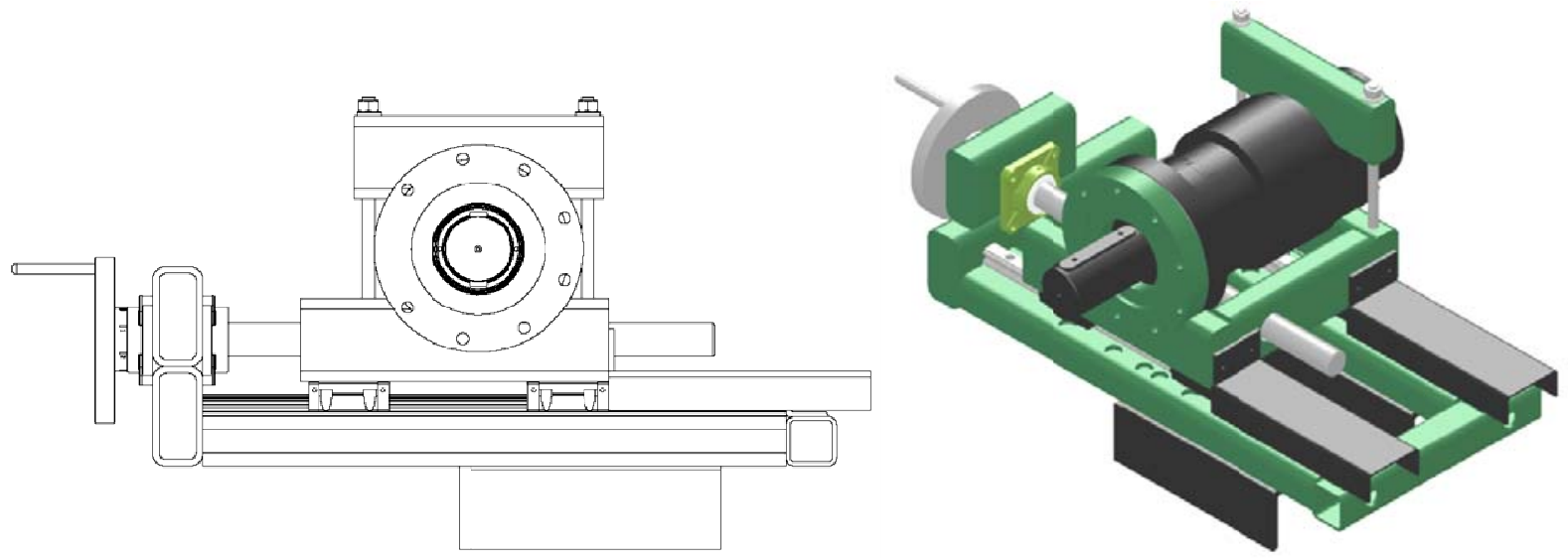

Fig. 3 Support of trolley actuator.
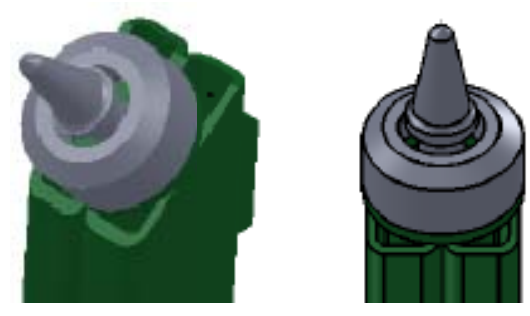

Fig. 4 The measuring arm with knife.

the hydraulic system is connected and the supply from the water-oil main in the mine is connected to sockets and the control unit (the device can also be supplied from a pump).

The system is furnished with a pressure regulator, the aim of which is to prevent the pressure value from exceeding the admissible level (21 MPa for the device), which may occur in the mine's main. The current value of pressure can be checked by means of a manometer attached with the device.

After measurements have been taken, the recorded results are further processed by means of a special software, which is an integral part of the device.

After assembling the whole instrument, a place for taking measurements should be prepared. In order to do that, a longitudinal vertical cavity should be made in the coal bed in which the measurement cutting knife will work. A cavity is made by mounting a levelling knife on the arm and performing a few cycles of work. After each pass of the knife, it should be withdrawn to the upper position and next the whole carriage should be shifted away from the coal bed by $1-2 \mathrm{~cm}$, by means of the knob. After the cavity has been prepared, it is necessary to mount the cutting knife and start up the measurement system. The next step is to switch on the device and perform a cutting procedure. The forces acting on the knife will be recorded. After each cutting cycle performed with the measurement knife, the cavity should be levelled by means of a levelling knife.

Coal resistance to cutting can be measured in coal beds having a thickness of 0.75 to $6.0 \mathrm{~m}$. The POU-BW/01-WAP device enables a maximum of 15 measurement cuts to be made with one mounting of the device at one height, without a necessity to shift the hydraulic props, which guarantees high accuracy of measurements. The measurement data coordinates are recorded by recording devices within an accuracy of 1 $\mathrm{mm}$. Due to a small number of elements, the device is easy to assemble, its operation is simple and maintenance - cheap.

As the device is equipped with force sensors and a pressure sensor, it is possible to determine the cutting forces from two independent measurement forces, which allows verifying the obtained results of measurements - the cutting force and the knife feed force. Moreover, owing to a pressure sensor, it is possible to determine an instantaneous cutting force of coal rock (the rock surrounding a coal bed).

POU-BW/01-WAP - a device for determining the resistance to cutting is unique on a global scale. It is a mobile device enabling measurements to be taken in 
both real and laboratory conditions. It reproduces the real character of work performed by a mining machine - a drum cutter-loader.

\section{Summary}

One of important areas of a mine's activity is proper operation of machines, which among others should consist in proper control over the rational and effective use of machines in the exploitation process [11].

The importance of measurements and evaluation of coal (rock) workability is confirmed by a large number of methods of its measurement developed in various research centres around the world.

The previously conducted investigations and analyses indicate that the value of this index exerts a considerable influence on the power, efficiency as well as durability and reliability of mining machines' work. It can also be concluded that this parameter has a decisive impact on energy consumption, installed power and dimensions of a mining machine, and, in consequence, affects the costs of purchase and maintenance. High powers installed on mining machines increase their dimensions and have an influence on the climatic threat, disorders in air flow, methane risk or, finally, a necessity to make headings with larger cross-sections.

The efficiency of a longwall working depends directly on properly selected machines and equipment of the longwall system. A properly selected longwall

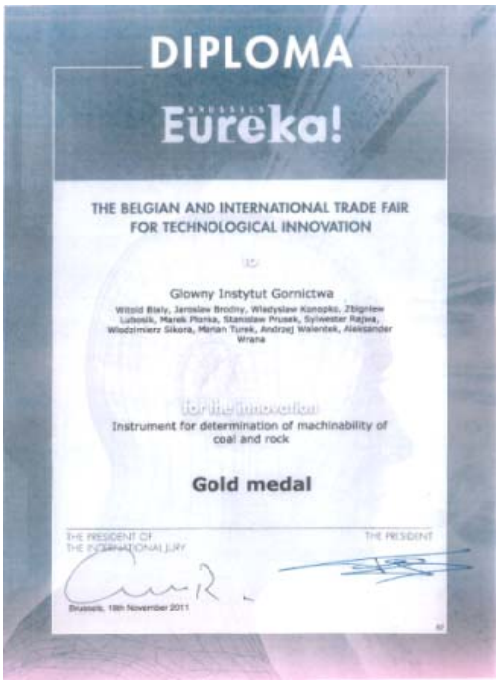

system must take into consideration the geological and mining conditions of the mined longwall.

For this reason, coal workability measurement will allow an optimal selection of mining machines' exploitation parameters and can become one of decisive factors for evaluating the possibility of effective exploitation of a particular plot or a coal bed. This problem concerns coal mining by means of both a plow or a cutter-loader.

Using the results of measurements, it is possible to determine the grade of coal, and, in consequence, the projected power of a longwall drum cutter-loader working in particular geological and mining conditions.

The devices presented in this article have been based on hi-tech solutions, both with regard to construction and measurements as well as the recording of measured values. They have an ATEX M2 Ex ib I Mb certificate, which allows their work in real conditions (mining plants) as a device intended for use in potentially explosive atmospheres - in accordance with Directive 94/9/EC.

The innovative solutions applied in the devices have been appreciated in the world. At the International Exhibition of Innovation, held annually in November, the devices were granted the following awards respectively:

- GIG device in 2011-GOLD MEDAL,

- POU-BW/01-WAP device in 2012-SILVER MEDAL.

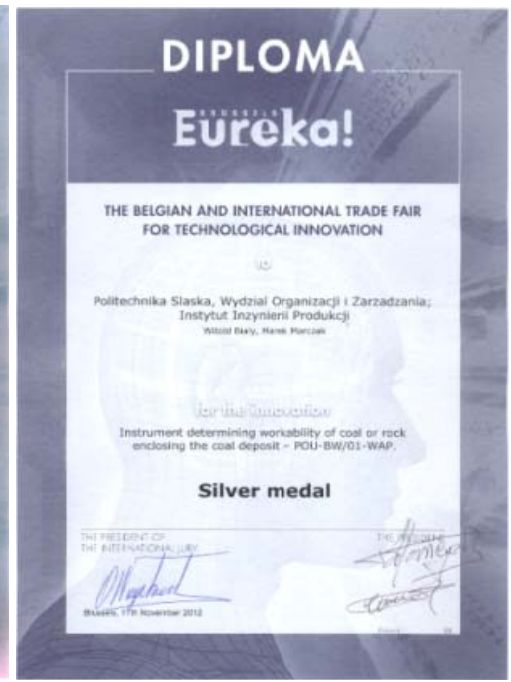


Moreover, in 2013 the device POU-BW/01-WAP received awards at exhibitions taking place in:

- Taiwan,

- Japan,

- Romania.
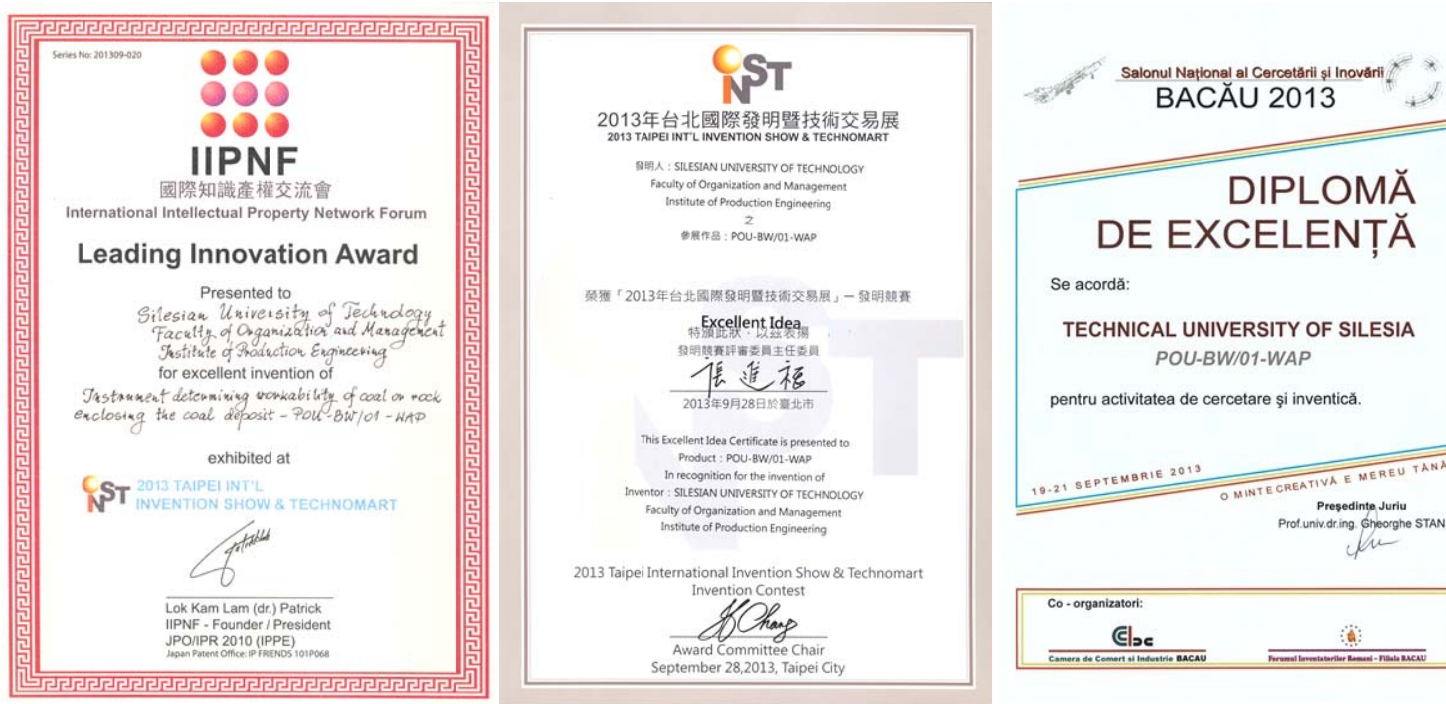
Se acordă:

TECHNICAL UNIVERSITY OF SILESIA POU-BW/01-WAP

pentru activitatea de cercetare şi inventică.
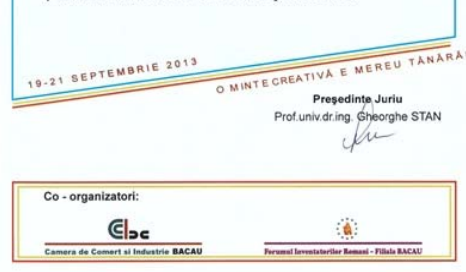

This device received in 2013 and 2014 a diploma of the Minister of Science and Higher Education.

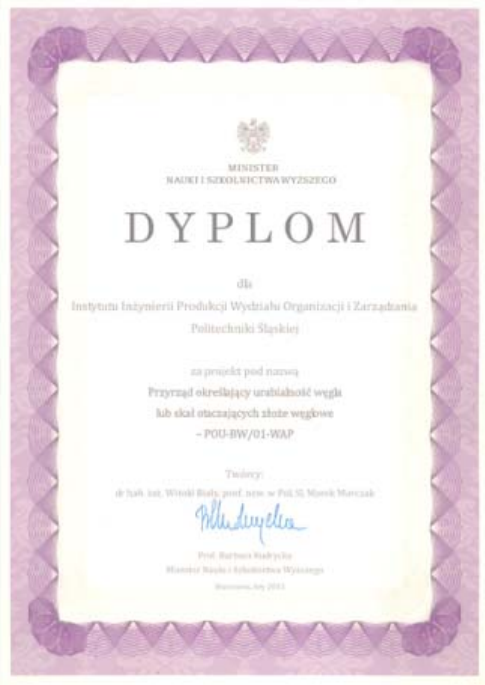

\section{References}

[1] Biały, W. 2011. The Selection of Optimal Method Determining Mechanical Properties of Coal Layers. Management Systems in Production Engineering, 26-30. ISSN 2299-0461.

[2] Biały, W. 2005. Empiryczne prognozowanie mocy ścianowych kombajnów bębnowych. Zeszyty Naukowe Politechniki Śląskiej seria: Górnictwo z., 262. Wydawnictwo Politechniki Śląskiej Gliwice 2005. ISSN 0372-9508.

[3] Biały, W. 2009. Volba dobývacich kombajnů na základě výzkumů rozpojitelnosti uhlí. VŠB-Technická univerzita

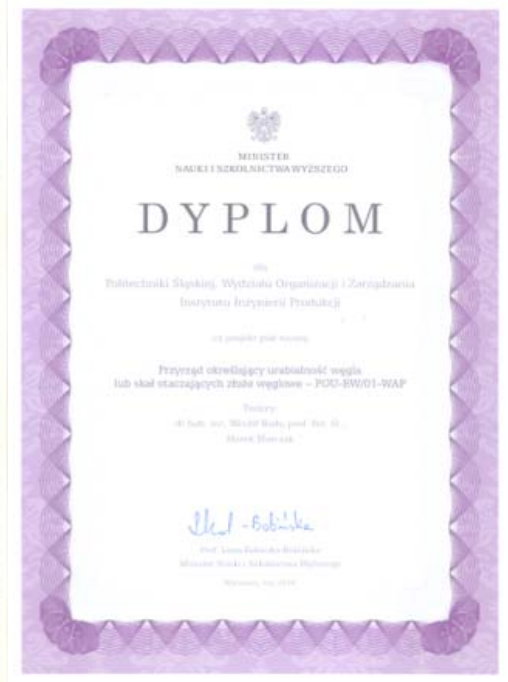

Ostrava, 122. ISBN 978-80-248-2032-3.

[4] Eskikaya, S., Bilgin, N., and Ozdemir, L. 2000. Development of Rapid Excavation Technologies for the Turkish Mining and Tunneling Industries. NATO TU Excavation SfS Program project report. Mining Engineering Department, Istanbul Technical University.

[5] Prusek, S., Rajwa, S., Wrana, A., and Walentek, A. 2011. Wykorzystanie nowoczesnych technik pomiarowych do oceny parametru skrawalności węla i skat $w$ warunkach in situ. Prace Naukowe GIG "Górnictwo i Środowisko", 302-7. ISSN 1643-7608.

[6] Prusek, S., Rajwa, S., Wrana, A., and Walentek, A. 2011. Ocena skrawalności pokładów węgla i skat otaczajacych 
$w$ warunkach dolowych $z$ wykorzystaniem przyrzqdu opracowanego w GIG. Nowe spojrzenie na technikę i technologię eksploatacji cienkich pokładów węgla kamiennego, 24-6, 123-31.

[7] Biały, W. 2015. Innovative Solutions Applied in Tools for Determining Coal Mechanical Proprerties. Management Systems in Production Engineering, 202-9. ISSN 2299-0461. Doi: 10.12914/MSPE-02-04-2015.

[8] Biały, W. 2014. "Coal Cutting Force Measurment Systems-(CCFM)." 14th SGEM GeoConference on Science and Technologies in Geology, Exploration and Mining, SGEM2014 Conference Proceedings, Vol. III, 91-8. ISBN 978-619-7105-09-4/ISSN 1314-2704.
[9] Biały, W. 2014. Zasoby węgla kamiennego. Urabialność pokładów węglowych. Wydawnictwo PA NOVA, 150. ISBN 978-83-937845-5-4.

[10] Dokumentacja Techniczno-Ruchowa Przyrządu POU-BW/01-WAP. Gliwice 2012.

[11] Peter, F. 2001. "Rethinking Pareto Analysis Maintenance Applications of Logarithmic Scatterplots." Journal of Quality Maintenance Engineering 4 (7): 252-63. ISSN 1355-2511.

[12] Myszkowski, M., and Paschedag, U. 2008. Longwall Mining in Seams of Medium Thickness-Comparison between Shearer and Plow. 21st Word Mining Congress. 